\title{
The Regulation of Glutamine Metabolism in Candida utilis: the Inactivation of Glutamine Synthetase
}

\author{
By A. R. FERGUSON AND A. P. SIMS* \\ School of Biological Sciences, University of East Anglia, Norwich, NOR 88 C
}

(Received 20 June 1973)

\begin{abstract}
SUMMAR Y
In Candida utilis a sudden increase in ammonia supply or a decrease in glucose supply can result in a rapid and extensive reduction in glutamine synthetase activity, a fall that is much faster than can be accounted for by the immediate repression of enzyme synthesis followed by the dilution of existing enzyme by the other cell proteins produced during continued growth. This decrease in enzyme activity is not caused by the build-up within the cell of an inhibitor of the enzyme, by the rapid turnover in vivo of the enzyme, or by the conversion of the enzyme from a more active to a less active form, but by the specific inactivation of the enzyme. Inactivation appears to be largely irreversible, and studies using inhibitors of protein synthesis indicate that the reappearance of the enzyme after removal of ammonia is dependent on de novo protein synthesis.

Glutamine synthetase activity can be estimated by using either the transferase assay or the synthetase assay: the ratio of these activities is virtually constant in preparations from yeast growing under a wide range of conditions and during inactivation and reappearance of the enzyme.
\end{abstract}

\section{INTRODUCTION}

In Candida utilis the amount of glutamine synthetase present varies with the nitrogen source provided for growth (Ferguson \& Sims, 1974). Enzyme specific activity is high whenever the nitrogen source supplied is growth-limiting, either as a consequence of its limited uptake from the medium or because it can be only slowly metabolized to generate the ammonia required for amide synthesis. The addition of ammonia or glutamine to yeast so adapted brings about a rapid and extensive fall in glutamine synthetase specific activity that is much faster than can be accounted for by immediate repression of enzyme synthesis followed by the dilution of existing enzyme by the other cellular proteins produced during continued growth (Ferguson \& Sims, I97I). In earlier papers we have discussed the physiological significance of this rapid decrease in enzyme activity. We have shown that it results in a decrease in the rate at which glutamine is synthesized (Sims \& Ferguson, 1972; 1974), and that it usually occurs when changed growth conditions have resulted in a large increase in the cell pool of glutamine and a decrease in that of glutamate (Ferguson \& Sims, 1974). A fall in glutamine synthetase activity in response to an over-production of glutamine or to a depletion of glutamate would thus appear to be an effective, if coarse, means of controlling the synthesis of glutamine. There are, however, a number of different conditions that can bring about the disappearance of the enzyme, and the catabolism of carbon compounds appears to be involved in a way we do not yet fully understand.

In this paper we examine the nature of this rapid decrease in enzyme activity. Loss of

* All communications should be addressed to A P S. 
activity could be due to the build-up within the cell of an inhibitor of the enzyme, to the rapid turnover in vivo of the enzyme, inactivation of the enzyme, or to conversion of the enzyme from a more active to a less active form. Preliminary results indicated that the disappearance of glutamine synthetase in yeast might be similar to the reversible inactivation of glutamine synthetase already described in a number of the Enterobacteriaceae (Mecke \& Holzer, 1966; Gancedo \& Holzer, 1968). We have therefore carried out experiments to determine if this decrease in glutamine synthetase activity is caused by enzyme inactivation, and if so, whether such inactivation is reversible.

\section{METHODS}

Organism and growth conditions. The strain of Candida utilis used was NCYC 737. The culture medium and the growth conditions used were described in Ferguson \& Sims (197I, I974).

Growth inhibitors. Actidione (cycloheximide) was obtained from Koch-Light Laboratories Ltd, Colnbrook. It was dissolved in a small quantity of $60 \%(\mathrm{v} / \mathrm{v})$ ethanol before being added to the medium. An equal volume of ethanol was added to control cultures. DL- $p$-Fluorophenylalanine was obtained from the Sigma London Chemical Co., London.

Preparation of crude yeast extracts and assay of enzyme activities. Crude extracts were prepared as described in Ferguson \& Sims (I97I). All enzyme assays were carried out at $30{ }^{\circ} \mathrm{C}$. For convenience of comparison, enzyme activities are given as percentages of those at the beginning of each experiment. When yeast was grown with glutamate, glutamine synthetase activity (measured by the synthetase assay) was between 120 and $150 \mathrm{mu} / \mathrm{mg}$ protein.

Glucose-6-phosphate dehydrogenase (D-glucose-6-phosphate: NADP oxidoreductase, EC. I.I. I.49). The enzyme was assayed by following NADP reduction at $340 \mathrm{~nm}$. The assay solution contained glucose-6-phosphate, $7.5 \mu \mathrm{mol}$; magnesium sulphate, $3 \mu \mathrm{mol}$; NADP, $\mathrm{I} \cdot 6 \mu \mathrm{mol}$; all in phosphate buffer, $0 . \mathrm{I} \mathrm{M}, \mathrm{pH} 7 \cdot 2$, in a total volume of $\mathrm{I} \cdot 5 \mathrm{ml}$. The assay was started by addition of enzyme extract.

NAD-specific glutamate dehydrogenase (L-glutamate: NAD oxidoreductase (deaminating), EC. I.4.I.2), see Ferguson \& Sims (I97I).

$N A D P$-specific glutamate dehydrogenase (L-glutamate: NADP oxidoreductase (deaminating), EC. I.4.1.4), see Ferguson \& Sims (1971).

Glutamate-oxaloacetate transaminase (L-aspartate: 2-oxoglutarate aminotransferase, EC. 2.6.I.I). A coupled assay was used in which the oxidation of NADH was followed at $340 \mathrm{~nm}$. The assay solution contained aspartate, $90 \mu \mathrm{mol}$; malate dehydrogenase (Sigma), about 500 units; NADH, $0.25 \mu \mathrm{mol}$; 2-oxoglutarate, $27 \mu \mathrm{mol}$; all in phosphate buffer, $0 . \mathrm{I} \mathrm{M}, \mathrm{pH} 7.5$, in a total volume of $\mathrm{I} \cdot 6 \mathrm{ml}$. Stock NADH was in phosphate buffer, $0.0 \mathrm{I} \mathrm{M}$, pH 8.6. The assay was started by addition of enzyme extract.

Glutamate-pyruvate transaminase (L-alanine: 2-oxoglutarate aminotransferase, EC. 2.6.I.2). A coupled assay was used in which the oxidation of NADH was followed at $340 \mathrm{~nm}$. The assay solution contained alanine, $90 \mu \mathrm{mol}$; lactate dehydrogenase (Sigma), about 500 units; NADH, $0.25 \mu \mathrm{mol}$; 2-oxoglutarate, $27 \mu \mathrm{mol}$; all in phosphate buffer, $0 . \mathrm{I} \mathrm{M}, \mathrm{pH} 7.5$, in a total volume of $\mathrm{I} \cdot 6 \mathrm{ml}$. The assay was started by addition of enzyme extract.

Glutamine synthetase (L-glutamate: ammonia ligase (ADP), EC. 6.3. I . 2). For synthetase assay, see Ferguson \& Sims (1974). For transferase assay, see Ferguson \& Sims (I971).

Isocitrate dehydrogenase (threo- $\mathrm{D}_{\mathrm{8}}$-isocitrate: NAD oxidoreductase (decarboxylating), EC. I.I.I.4I). The enzyme was assayed by following NAD reduction at $340 \mathrm{~nm}$. The 


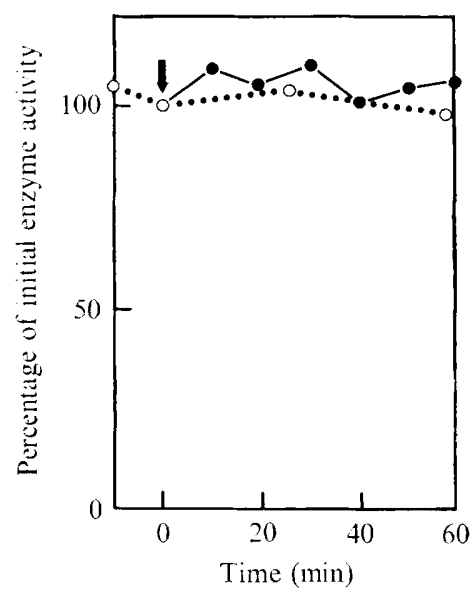

Fig. I

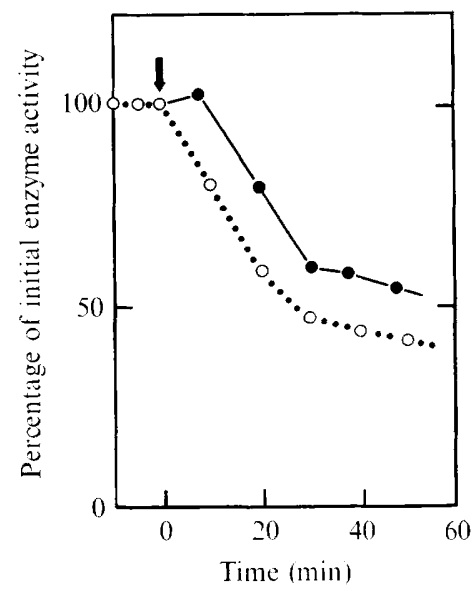

Fig. 2

Fig. I. Effects of actidione on glutamine synthetase specific activity (measured by transferase assay) in yeast growing with glutamate (initially $6 \mathrm{~mm})$. $\odot$, Actidione $(50 \mu \mathrm{g} / \mathrm{ml})$ added at time shown; and $\bigcirc$, control culture.

Fig. 2. Effects of actidione on the disappearance of glutamine synthetase (measured by transferase assay). Ammonia $(6 \mathrm{~mm})$ was added at the time shown to yeast growing with glutamate (initially $6 \mathrm{~mm})$. The culture was then immediately split: $\bigcirc$, actidione $(50 \mu \mathrm{g} / \mathrm{ml})$ added; and $\bigcirc$, control culture.

assay solution contained trisodium isocitrate, $4 \mu \mathrm{mol}$; magnesium sulphate, $6 \mu \mathrm{mol}$; NAD, $0.25 \mu \mathrm{mol}$; all in phosphate buffer, $0 . \mathrm{I} \mathrm{M}, \mathrm{pH} 7.5$, in a total volume of $\mathrm{I} \cdot 5 \mathrm{ml}$. The assay was started by addition of enzyme extract.

Calculation of the repression line. It was assumed that the enzyme being studied was not subject to turnover, that its synthesis was immediately repressed on the change in nutritional conditions, and that existing enzyme was then diluted out by the other proteins produced during continued growth. The rate of protein synthesis was measured by pipetting samples of the yeast culture into ethanol, dissolving the precipitated protein in $0.72 \mathrm{~N}-$ $\mathrm{NaOH}$, and then estimating the protein as described below.

Analytical procedures. Cell amino acids were extracted, separated, and estimated as described in Ferguson \& Sims (I974). Protein (I to $1.5 \mathrm{mg}$ ) was precipitated in ethanol and estimated by the method of Lowry, Rosebrough, Farr \& Randall (195I) with crystalline bovine serum albumin as protein standard.

\section{RESULTS}

\section{Enzyme inhibition, enzyme turnover and enzyme inactivation}

Addition of ammonia to glutamate-grown yeast results in a rapid fall in glutamine synthetase specific activity. This is not caused by the build-up of an inhibitor of the enzyme, because studies with both crude and partially purified preparations of glutamine synthetase have shown that neither glutamine itself, nor the possible end-products of its metabolism, cause any significant inhibition of enzyme activity (A. P. Sims \& A. R. Ferguson, unpublished). In addition, physiological experiments have confirmed that feedback inhibition does not play any role in the regulation of glutamine synthesis in vivo (Sims \& Ferguson, 1974). Crude enzyme preparations were made from yeast that had been growing on glutamate and had 


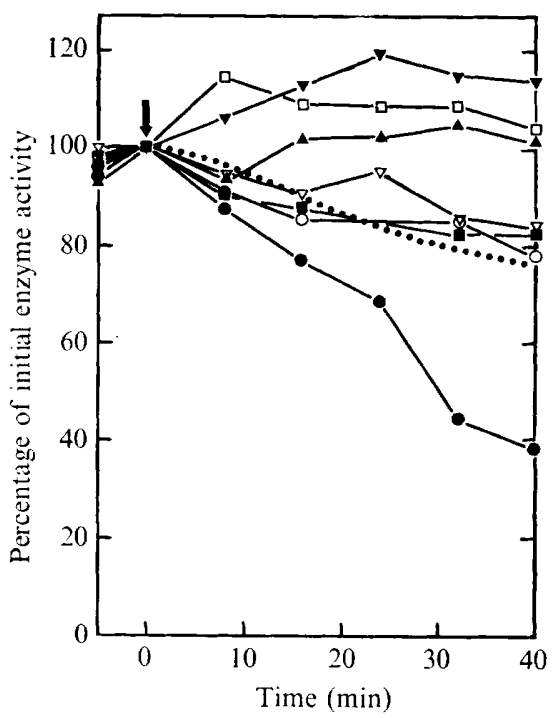

Fig. 3. Specificity of inactivation of glutamine synthetase. Ammonia (6 mm) was added at the time shown to yeast growing with glutamate (initially $6 \mathrm{mM}$ ). $\nabla$, Glucose-6-phosphate dehydrogenase; 口, NAD-specific glutamate dehydrogenase; $\bigcirc$, NADP-specific glutamate dehydrogenase; $\square$, glutamate-oxaloacetate transaminase; $\nabla$, glutamate-pyruvate transaminase; $\boldsymbol{O}$, glutamine synthetase (synthetase assay); $\boldsymbol{\Lambda}$, isocitrate dehydrogenase; and ..., line of repression.

then lost most of its glutamine synthetase after the addition of ammonia to the culture medium: when such enzyme preparations were de-salted by passage through Sephadex G-25 columns, there was no recovery of the lost activity. Furthermore, when these preparations were mixed with different amounts of crude preparations from glutamate-grown yeast, the resulting specific activity was always proportional to the specific activities and relative amounts mixed of the two preparations. It would thus seem that disappearance of enzyme activity was not caused by the build-up of an inhibitor of the enzyme.

It is possible that, under normal physiological conditions, glutamine synthetase is subject to very rapid turnover, and that only when further synthesis of the enzyme is prevented (as on the addition of ammonia) does this turnover become apparent. If the enzyme were subject to rapid turnover then addition of an inhibitor of protein synthesis of glutamate-grown yeast might be expected to have the same effect as the addition of ammonia. This possibility was tested by using actidione, which, in yeast, can inhibit the formation of cytoplasmic proteins, including glutamine synthetase (see, for example, Fig. 6 below), and can completely prevent the appearance of inducible enzymes such as nitrate reductase (A. R. Ferguson, J. Toone \& P. M. Nurse, unpublished). At the levels at which it was used, actidione had no effect on the in vitro activity of glutamine synthetase. When it was added to yeast growing on glutamate there was actually a very slight increase in glutamine synthetase specific activity (Fig. I): although the total enzyme activity of the culture remained unchanged, there was a small but significant decrease in total-protein content. Had the enzyme been turning over rapidly then addition of actidione, and consequent inhibition of protein synthesis, should have resulted in a rapid fall in enzyme specific activity. Actidione can, however, protect some enzymes against inactivation, e.g. it protects nitrate reductase of Ustilago maydis against the inactivation brought about by ammonia (Lewis \& Fincham, I970). In yeast, actidione did not prevent the disappearance of glutamine synthetase caused by the addition of ammonia (Fig. 2); we have 
therefore concluded that under the experimental conditions used it was unlikely that the enzyme was turning over rapidly. Hence it would appear that the fall in glutamine synthetase on changes in ammonia availability is caused by the in vivo inactivation of the enzyme.

\section{Specificity of inactivation}

On addition of ammonia to glutamate-grown yeast (Fig. 3), glutamine synthetase was inactivated but not the other enzymes tested; the specific activities of some enzymes, e.g. isocitrate dehydrogenase, remained unchanged, others such as alanine aminotransferase and aspartate aminotransferase increased slightly, whereas glucose-6-phosphate dehydrogenase and the two glutamate dehydrogenases fell at the rate predicted for repression. We have found, however, that conditions that bring about inactivation of glutamine synthetase can sometimes also bring about inactivation of the NAD-specific glutamate dehydrogenase (Ferguson \& Sims, 1971). The mechanisms by which the two enzymes are inactivated appear to be distinct and are clearly subject to different controls. Addition of ammonia to nitrategrown yeast does not cause inactivation of nitrate reductase.

\section{Synthetase and transferase activities}

Glutamine synthetase from various sources - animals, plants, or micro-organisms - can be assayed by a number of different procedures, the most commonly used being:

(a) Synthetase assay

$$
\mathrm{L}-\text { Glutamate }+ \text { hydroxylamine }+\mathrm{ATP} \stackrel{\mathrm{Mg}^{2+}}{\rightleftharpoons} \mathrm{L} \text { glutamylhydroxamate }+\mathrm{ADP}+\mathrm{P}_{\mathrm{i}}
$$

(b) Transferase assay

$$
\text { L-Glutamate + hydroxylamine } \underset{\mathrm{ADP}, \mathrm{AsO}_{4}{ }^{2+}}{\stackrel{\mathrm{Mn}^{2+}}{\rightleftharpoons}} \mathrm{L} \text { glutamylhydroxamate + ammonia }
$$

For enzyme preparations from yeast, the transferase assay is about six times more sensitive than the synthetase assay and is therefore frequently used in preference.

The inactivation of glutamine synthetase that occurs in yeast is superficially very similar to that observed in Escherichia coli: a sudden increase in ammonia availability results in a rapid fall in the enzyme activity as measured by the synthetase assay. The bacterial enzyme has been studied very intensively and has been shown to exist in a number of forms that differ from one another in the number of covalently bound adenyl groups (for reviews see Shapiro \& Stadtman, 1970; Holzer \& Duntze, 1971). Adenylation results in marked changes in the properties of the enzyme: a decrease in synthetase activity, changes in divalent ion specificity (from $\mathrm{Mg}^{2+}$ to $\mathrm{Mn}^{2+}$ ), changes in susceptibility to cumulative feedback inhibition by products of glutamine metabolism, and substantial shifts in $\mathrm{pH}$ optima (Stadtman et al. 1970). With the assay procedures normally used, changes in the state of adenylation are reflected by changes in the ratio of synthetase activity:transferase activity. Thus on the addition of ammonia to cultures of $E$. coli, there is an increase in the extent to which the enzyme is adenylated, and this results in a rapid loss of synthetase activity ('inactivation' of the enzyme) and a very much smaller reduction in transferase activity (Mecke \& Holzer, I966; Mecke, Wulff \& Holzer, I966). The state of adenylation of the enzyme varies with the nutrient conditions under which the bacteria are growing and this is shown by changes in the ratio of synthetase activity:transferase activity.

In contrast, this ratio of synthetase activity: transferase activity was virtually constant in 


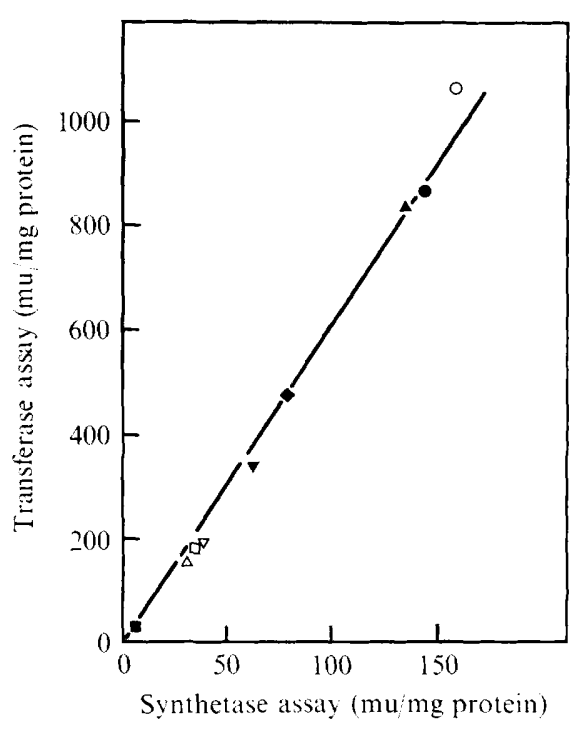

Fig. 4

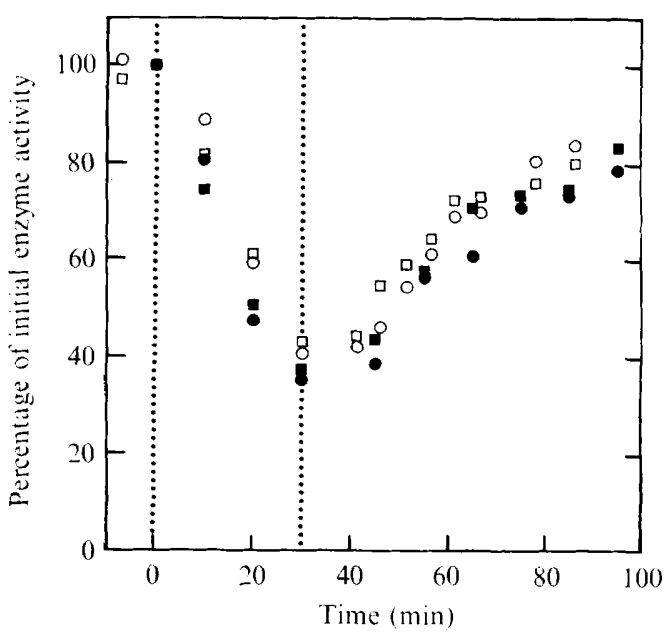

Fig. 5

Fig. 4. Relationship between transferase activity and synthetase activity in crude extracts of yeast growing with different sources of nitrogen (initially $20 \mathrm{mM}$ ). Transferase activity:synthetase activity $=5.7 ;$ coefficient of covariance $r=+0.995$. , Alanine; $\triangle$, ammonia; $\square$, ammonia and glutamate; $\bigcirc$, aspartate; $\boldsymbol{\Delta}$, glutamate; $\boldsymbol{\nabla}$, glutamine; $\diamond$, glycine; $\nabla$, nitrate; and $\nabla$, urea.

Fig. 5. Changes in glutamine synthetase specific activity, as measured by the synthetase and transferase assays, on the addition and subsequent removal of ammonia (at times indicated by dotted lines). $\bigcirc$, Synthetase assay, and $\square$, transferase assay, control culture, actidione experiment (for experimental details see legend to Fig. 6). @, Synthetase assay, and $\boldsymbol{\square}$, transferase assay, control culture, $p$-fluorophenylalanine experiment (Fig. 7). $r=+0.963$.

yeast growing under different conditions, e.g. when grown with different compounds as sources of nitrogen (Fig. 4). Furthermore, the two activities in yeast responded in a similar manner to changed growth conditions. Thus on inactivation, there was no change in the ratio synthetase activity:transferase activity; on the addition of ammonia to glutamategrown yeast there was an equivalent fall in the synthetase and transferase activities, and on resuspension of the yeast in medium containing glutamate as sole nitrogen source, the two activities increased to a similar extent (Fig. 5). When different assay conditions were used (e.g. when the transferase was assayed at $\mathrm{pH} 5.8$ and not $\mathrm{pH} 6.5$ ) the synthetase:transferase ratio, although different, remained constant throughout an experiment. Either assay can therefore be used to follow relative changes in specific activity.

Other studies have shown that inactivation of glutamine synthetase does not result in any changes in susceptibility to feedback inhibition or in affinity for the substrates ammonia and glutamate (Sims \& Ferguson, I972). Furthermore, under all the conditions tested the synthetase activity has a specific requirement for $\mathrm{Mg}^{2+}$ and does not show any dependence on $\mathrm{Mn}^{2+}$. The bacterial and yeast enzymes differ markedly in their properties, and although the regulatory significance of inactivation is probably very similar in the two organisms, the mechanisms by which it is achieved are apparently very different. Inactivation of the bacterial enzyme is reversible whereas, as is shown in the next section, that of the yeast enzyme is almost certainly irreversible. 


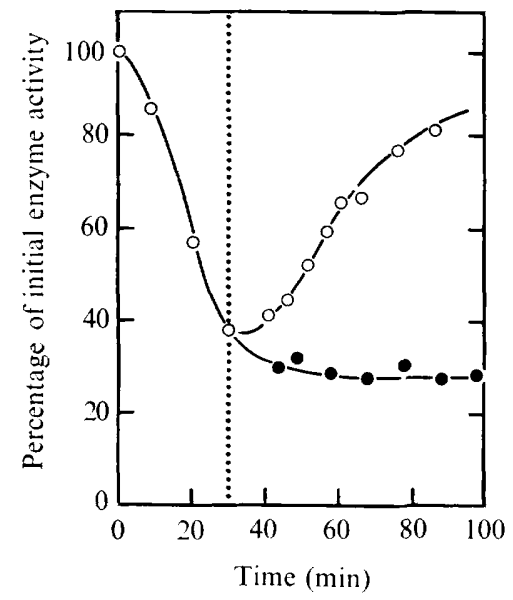

Fig. 6. Effects of actidione on the reappearance of glutamine synthetase (measured by synthetase assay) after inactivation. At time 0 , ammonia $(6 \mathrm{~mm})$ was added to yeast growing with glutamate (initially $6 \mathrm{~mm}$ ). After $30 \mathrm{~min}$ the culture was filtered, washed and resuspended in ammonia-free medium containing glutamate $(6 \mathrm{~mm})$. The culture was split: $\bigcirc$, actidione $(50 \mu \mathrm{g} / \mathrm{ml})$ added; and $\mathrm{O}$, control culture.

\section{Recovery of glutamine synthetase activity}

Addition of ammonia to glutamate-grown yeast resulted in the inactivation of glutamine synthetase; on subsequent removal of the ammonia, by resuspension of the yeast into medium containing only glutamate as nitrogen source, the enzyme specific activity returned rapidly almost to its previous level (Fig. 5). This reappearance of enzyme activity could be because of either the synthesis of new enzyme or the reactivation of enzyme previously inactivated. One accepted way of deciding whether an increase in enzyme activity requires synthesis of new enzyme is to establish whether it is prevented by inhibitors of protein synthesis. Addition of actidione to yeast completely prevented the restoration of glutamine synthetase activity after the removal of ammonia (Fig. 6), and this could be taken as an indication that the process was dependent on de novo protein synthesis. However, because actidione blocks protein synthesis, it will also affect the rates at which amino acids are withdrawn from the metabolic pools and hence will affect the size of the pools. Thus in the experiment described in Fig. 6 , the addition of ammonia to glutamate-grown yeast resulted in a rapid increase in the pool of glutamine and on resuspension of the yeast in glutamate-containing medium the pool fell rapidly (from about 200 to II $5 \mu \mathrm{mol} / \mathrm{g}$ fresh wt in $50 \mathrm{~min}$ ), but when actidione was present in the resuspending medium then the pool of glutamine remained high (in 50 min it fell only from 200 to $\mathrm{I} 65 \mu \mathrm{mol} / \mathrm{g}$ fresh wt). Such differences in the behaviour of the amino acid pools could result in misleading conclusions being drawn from experiments in which actidione was being used as an inhibitor of protein synthesis. We have already found (Sims \& Ferguson, 1972; 1974; Ferguson \& Sims, 1974) that whereas the inactivation of glutamine synthetase can frequently be associated with a rapid increase in the glutamine pool and an equally large depletion of the glutamate pool, the reappearance of enzyme activity usually occurs when there is a decrease in the pool of glutamine and in increase in that of glutamate. Thus in the experiment described, actidione could have been blocking the reappearance of the synthetase, not by direct inhibition of protein synthesis, but by causing changes in the amino acid pools.

To test whether the elevation of the glutamine pool had been blocking a reversible re- 


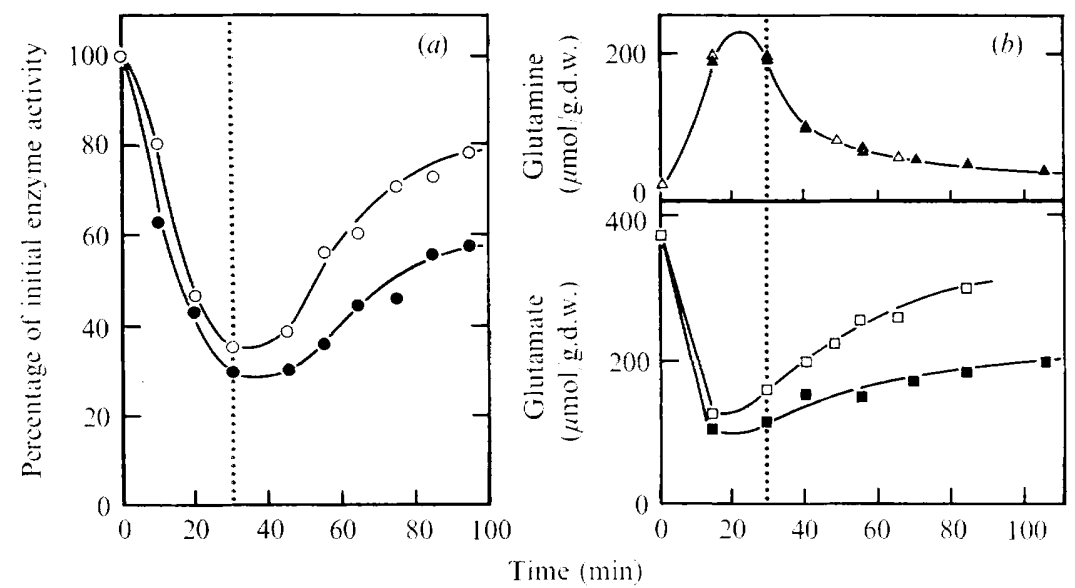

Fig. 7. Effects of $p$-fluorophenylalanine on $(a)$ the reappearance of glutamine synthetase and $(b)$ the behaviour of the amino acid pools in yeast subjected to changes in nitrogen supply. A yeast culture growing on glutamate (initially $6 \mathrm{~mm}$ ) was split. Ammonia ( $6 \mathrm{~mm}$ ) and $p$-fluorophenylalanine $(200 \mu \mathrm{g} /$ $\mathrm{ml}$ ) were added to half at time o. After $30 \mathrm{~min}$, this culture was filtered, washed and resuspended in ammonia-free medium containing glutamate $(6 \mathrm{~mm})$ and $p$-fluorophenylalanine $(300 \mu \mathrm{g} / \mathrm{ml})$; g.d.w. = g dry weight. The control culture was subjected to the same changes in nitrogen supply but was not exposed to the inhibitor. (a) Glutamine synthetase specific activity (as measured by synthetase assay): $\bigcirc$, culture exposed to $p$-fluorophenylalanine; and $\bigcirc$, control culture. (b) Amino acid pools: $\boldsymbol{\Delta}$, glutamine; $\boldsymbol{\square}$, glutamate in culture exposed to $p$-fluorophenylalanine; $\Delta$, glutamine; $\square$, glutamate in control culture.

activation of glutamine synthetase we used a different inhibitor of protein synthesis, $p$ fluorophenylalanine. This does not prevent protein synthesis completely, but is believed to function by becoming incorporated into proteins which are therefore physiologically inactive (Baker, Johnson \& Fox, I958). Continued synthesis of proteins, even of defective proteins, ensures that in the presence of the inhibitor there is still withdrawal of amino acids from the metabolic pools. Addition of $p$-fluorophenylalanine appreciably reduced the rate at which glutamine synthetase activity reappeared following the removal of ammonia (Fig. $7 a$ ). Measurements of the amino acid pools (Fig. 7) showed that the presence of the inhibitor had no effect on the rate at which the glutamine pool decreased, and thus the reduced rate of enzyme reappearance was not a consequence of an elevation of the glutamine pool. Addition of $p$-fluorophenylalanine did not completely prevent the reappearance of the synthetase, and preliminary studies have shown that the inhibitor blocked the induction of nitrate reductase in yeast to a similar extent (J. Toone and A. R. Ferguson, unpublished). This is presumably because $p$-fluorophenylalanine was competing with the endogenously synthesized pool of phenylalanine for incorporation into protein (Fowden, Lewis \& Tristram, I967).

Results from these and similar experiments with inhibitors were all consistent with the reappearance of glutamine synthetase being caused by de novo protein synthesis, but they do not allow us to eliminate entirely the possibility that inhibitors were indirectly affecting protein synthesis through their effects on amino acid metabolism. We therefore sought to design experiments in which the addition of inhibitor did not produce a derangement of the amino acid pools, particularly those of glutamate and glutamine. Inactivation of glutamine synthetase can occur not only after changes in ammonia availability but also after changes in the carbon supply (Ferguson \& Sims, 1974). Thus when glutamate- or aspartate-grown yeast was transferred to a medium lacking both glucose and a nitrogen source, the enzyme 

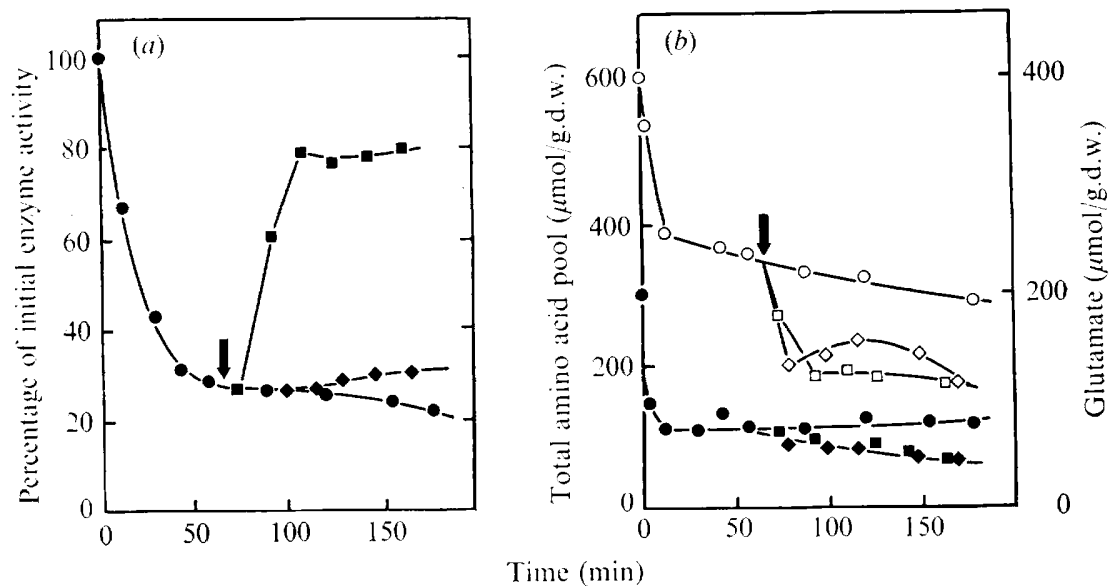

Fig. 8. Effects of actidione on $(a)$ the reappearance of glutamine synthetase and $(b)$ the behaviour of the amino-acid pools in yeast subjected to changes in nutrient supply. At time 0 , glutamate-grown yeast was transferred to medium lacking both glutamate and glucose. After 65 min, the culture was split into three parts: the first was retained as control and lacked both glutamate and glucose; to the second, glucose ( $10 \mathrm{mg} / \mathrm{ml})$ was added; and to the third, glucose $(10 \mathrm{mg} / \mathrm{ml})$ and actidione $(50 \mu \mathrm{g} / \mathrm{ml})$ were added. (In a separate experiment, details of which are not shown, it was established that the addition of actidione did not markedly affect the uptake and metabolism of $\left[\mathrm{U}-{ }^{14} \mathrm{C}\right] \mathrm{glucose}$ for at least $35 \mathrm{~min}$ ). (a) Glutamine synthetase specific activity (as measured by transferase assay): $\boldsymbol{0}$, control culture, lacking both glutamate and glucose; $\mathbf{a}$, glucose added after $65 \mathrm{~min}$; and $\bullet$, glucose and actidione added after $65 \mathrm{~min}$. (b) Amino acid pools: $\bigcirc$, glutamate; $\bigcirc$, total amino acid pool in control; culture lacking both glutamate and glucose; $\square$, glutamate; $\square$, total amino acid pool in control culture to which glucose was added at $65 \mathrm{~min} ; \diamond$, glutamate; and $\diamond$, total amino acid pool in culture to which glucose and actidione were added at $65 \mathrm{~min}$.

was rapidly inactivated (Fig. $8 a$ ). Under these conditions there is also a large fall in the pool of glutamate and a steady decline in that of glutamine (A. P. Sims and V. Box, unpublished). The reappearance of glutamine synthetase that occurred on the restoration of the glucose supply was almost completely blocked by the simultaneous addition of actidione (Fig. $8 a$ ). Measurements made of the total amino acid and glutamate pools confirmed that it was the presence of actidione rather than differential changes in the pools of amino acids that was responsible for preventing reappearance of enzyme. In this experiment, glutamine synthetase reappeared on the addition of glucose despite a significant fall in the cell concentration of glutamate (Fig. $8 b$ ). In a separate experiment (not shown here) we established that the uptake of glucose into the yeast was not inhibited by actidione. These results all suggest that the inactivation of glutamine synthetase was essentially irreversible and that the reappearance of activity was dependent upon de novo protein synthesis. Addition of actidione did not completely prevent the reappearance of enzyme activity (Fig. $8 a$ ) and this could mean that the inactivation processes involved several steps, only one of which was reversible. The exact mechanism of the inactivation will be further discussed in a later paper (Sims, Toone \& Box, 1974).

\section{DISCUSSION}

Changes in the nutritional conditions under which a micro-organism is growing can frequently result in repression of the synthesis of some of its enzymes. Occasionally the specific activity of an enzyme decreases more rapidly than can be accounted for by the immediate cessation of enzyme synthesis followed by dilution of existing enzyme by the 
other cell proteins produced during continued growth. This may be due simply to the rapid turnover in vivo of the enzyme, as for example with $\delta$-aminolaevulinic acid synthase in photosynthetic bacteria (Lascelles, 1968), or to the loss of an essential cofactor because of changes in cofactor binding or biosynthesis (Mandelstam, 1954). Some enzymes can exist in two forms, differing in their activity and enzymically interconverted by covalent modifications such as adenylation, phosphorylation, or adenosine diphosphate ribosylation (Holzer $\&$ Duntze, 1971). A rapid fall in the in vivo specific activity of such an enzyme can be brought about by its conversion from the more active to the less active form. Binding of ligands to the active centre or to any other part of an enzyme molecule can frequently affect both its stability and activity in vitro, and it is possible that this is also important in vivo (Nijkamp, 1969). Control of the activity of a number of other enzymes is known to involve proteinprotein interactions, e.g. a reversible interaction between arginase and ornithine transcarbamylase is one of the controls keeping separate the antagonistic pathways of arginine synthesis and degradation in Saccharomyces cerevisiae (Wiame, 1971).

These various mechanisms probably account for most instances of what might at first seem to be enzyme inactivation, but there still remain a number of enzymes that are apparently subject to rapid but irreversible inactivation. Our results suggest that glutamine synthetase from Candida utilis is one such enzyme. A sudden increase in ammonia availability, the addition of glutamine or the removal of the energy source, brings about a rapid fall in glutamine synthetase specific activity. This is not merely a consequence of extensive protein turnover, but instead, appears to be due to the specific inactivation of the enzyme. Furthermore, inactivation is probably irreversible in that full activity cannot be recovered under conditions that inhibit protein synthesis. These conclusions have been confirmed and extended by the more definitive methods described in a later paper (Sims et al. 1974). There are many other enzymes that are similarly inactivated. In yeast, 'galactozymase' (the galactose-inverting system now known to consist of several enzymes) disappears on the addition of glucose (Spiegelman \& Reiner, 1947). Enzymes of the maltose utilization pathway are lost when yeast is transferred to nitrogen-free medium containing glucose (Robertson \& Halvorson, I 957). Addition of glucose causes the inactivation of malate dehydrogenase, the synthesis of which is derepressed when Saccharomyces cerevisiae is grown with acetate as sole carbon source (Witt, Kronau \& Holzer, 1966; Ferguson, Boll \& Holzer, 1967). Subsequent work (van Rijn \& van Wijk, 1972) has shown that only the cytoplasmic malate dehydrogenase, which behaves as a gluconeogenic enzyme, is subject to inactivation, and the mitochondrial malate dehydrogenase is merely repressed. The addition of glucose to different yeasts growing on acetate also results in the irreversible inactivation of fructose- $1,6-$ diphosphatase (Gancedo, I97I).

Such enzyme inactivation is not restricted to yeasts. For example, when the green alga Chlorella fusca var. vacuolata (also referred to as Chlorella pyrenoidosa) is grown with acetate as sole carbon source there is a considerable rise in isocitrate lyase specific activity. Transfer of acetate-adapted Chlorella to medium containing glucose results in a rapid fall in isocitrate lyase activity that can be correlated with a loss of isocitrate lyase enzyme protein (John, Thurston \& Syrett, 1970). This too is a specific process and not simply a result of general protein turnover or of a high rate of turnover of the enzyme. Studies with inhibitors (Thurston, John \& Syrett, 1973) have shown that the process occurs in two steps: inactivation of the enzyme is followed by the degradation of enzyme protein. A number of other enzymes from micro-organisms are also subject to inactivation, e.g. nitrate reductase in Ustilago maydis (Lewis \& Fincham, 1970) and in Neurospora crassa (Subramanian \& Sorger, I972), phosphatase in Euglena gracilis (Liedtke \& Ohmann, I969), ribulose-I,5-diphosphate 
carboxylase in Hydrogenomonas spp. (Kuehn \& McFadden, 1968) and Chromatium (Hurlbert \& Lascelles, 1963), and the NAD-specific glycerol dehydrogenase in Aerobacter aerogenes (Lin, Levin \& Magasanik, 1960). Rapid inactivation - and possibly reactivation - of enzymes may play an important role in the regulation of enzyme activity in mammalian cells (see Schimke \& Doyle, 1970).

If the synthesis of an enzyme is repressed and existing enzyme is diluted out by the production of other proteins, then the rate at which the specific activity of the enzyme decreases will depend on the growth rate (Pollock, 1958). Enzyme 'de-adaptation' or 'reversion' is thus a slow process: after one generation, the concentration of the repressed enzyme will have halved, and after a further generation's growth it will have dropped to a quarter. However, under the changed growth conditions that have resulted in the repression of enzyme synthesis, the continued functioning of the enzyme can be undesirable, and thus repressible enzymes are frequently also subject to endproduct inhibition, catabolite inhibition or to inactivation. In some cases the rapid inactivation of the enzyme is of obvious advantage to the organism. Thus in yeast, inactivation of glutamine synthetase, an enzyme not susceptible to direct endproduct inhibition, can prevent overproduction of glutamine and a draining of the glutamate pool with consequent effects on other metabolic pathways (Sims \& Ferguson, 1972, 1974). Similarly, inactivation of nitrate reductase by ammonia (Lewis \& Fincham, 1970; Subramanian \& Sorger, 1972) could prevent the unnecessary assimilation of nitrate when more reduced forms of nitrogen are available for growth. The enzymes in yeast that are inactivated on the addition of glucose - malate dehydrogenase, isocitrate lyase and succinate-cytochrome $c$ oxidoreductase - are those concerned with gluconeogenesis or the supplying of oxaloacetate. Their inactivation is not surprising because glycolysis and gluconeogenesis would not be expected to occur simultaneously (Chapman \& Bartley, I968). Similarly, inactivation of fructose-I,6-diphosphatase after the addition of glucose (Gancedo, I97I) would prevent a 'futile cycle' in which fructose-6-phosphate was first phosphorylated and then dephosphorylated. In other examples, however, it is more difficult immediately to recognize any physiological advantage in inactivation: there seems to be no reason why addition of phosphate should cause the inactivation of the derepressed acid phosphatases in Saccharomyces mellis (Weimberg \& Orton, 1965) and Euglena gracilis (Price, I962; Liedtke \& Ohmann, 1969), and no advantage in the inactivation of aminoacyl-transfer RNA synthetases in Escherichia coli under conditions of restricted or interrupted amino acid supply (Williams \& Neidhardt, 1969). Perhaps inactivation here is merely an unavoidable consequence of amino acid limitation rather than a regulatory response by the cell.

It has been suggested that a control mechanism that involves the rapid and irreversible inactivation of a key enzyme is not 'intellectually satisfying' (Lascelles, I968). Nevertheless, the results described and the literature cited in this paper make it clear that a number of important enzymes are subject to rapid and irreversible inactivation. Although it may seem to be a crude way of controlling enzyme activity it can also be a very effective way. Thus our studies using isotopically-labelled ammonia (Sims \& Ferguson, I972; 1974) have established that in yeast the inactivation of glutamine synthetase results in an immediate fall in the rate at which glutamine is synthesized. Inactivation appears to be an irreversible process but if nutritional conditions change in such a way that rates of glutamine synthesis are no longer adequate to meet the requirements of the cell, then there can be a very rapid increase in enzyme amount. Rapid and irreversible inactivation of the synthetase coupled with a mechanism allowing for its rapid synthesis when needed would provide a precise and sensitive means for regulating the biosynthesis of glutamine. 
This work was supported by the Science Research Council by grant B/SR/5I I6. We thank Miss V. Box, Mrs J. Stephens and Mrs J. Toone for their skilled technical assistance, and E. G. Bollard for reading the manuscript.

\section{REFERENCES}

BAKER, R. S., Johnson, J. E. \& Fox, S. W. (I958). Incorporation of $p$-fluorophenylalanine into proteins of Lactobacillus arabinosus. Biochimica et biophysica acta 28, 31 8-327.

Chapman, C.\& BartLey, W. (I968). The kinetics of enzyme changes in yeast under conditions that cause the loss of mitochondria. Biochemical Journal 107, 455-465.

Ferguson, A. R. \& Sims, A. P. (I97I). Inactivation in vivo of glutamine synthetase and NAD-specific glutamate dehydrogenase: its role in the regulation of glutamine synthesis in yeasts. Journal of General Microbiology 69, 423-427.

Ferguson, A. R. \& Sims, A. P. (1974). The regulation of glutamine metabolism in Candida utilis: the role of glutamine in the control of glutamine synthetase. Journal of General Microbiology 80, 159-171.

Ferguson, J. J., Jun., Boll, M. \& Holzer, H. (1967). Yeast malate dehydrogenase: enzyme inactivation in catabolite repression. European Journal of Biochemistry I, $21-25$.

Fowden, L., LeWIS, D. \& Tristram, H. (1967). Toxic amino acids: their action as antimetabolites. Advances in Enzymology 29, 89-163.

GANCEDO, C. (1971). Inactivation of fructose-1,6-diphosphatase by glucose in yeast. Journal of Bacteriology I07, $40 \mathrm{I}-405$.

GANCEDO, C. \& Holzer, H. (1968). Enzymatic inactivation of glutamine synthetase in Enterobacteriaceae. European Journal of Biochemistry 4, 190-192.

Holzer, H. \& Duntze, W. (I971). Metabolic regulation by chemical modification of enzymes. Annual Review of Biochemistry 40, 345-374.

HurLbert, R. E. \& LASCELles, J. (1963). Ribulose diphosphate carboxylase in Thiorhodaceae. Journal of General Microbiology 33, 445-458.

John, P. C. L., Thurston, C. F. \& Syrett, P. J. (1970). Disappearance of isocitrate lyase enzyme from cells of Chlorella pyrenoidosa. Biochemical Journal x19, 913-9I9.

KueHn, G. D. \& MCFADDEN, B. A. (1968). Factors affecting the synthesis and degradation of ribulose-1,5diphosphate carboxylase in Hydrogenomonas facilis and Hydrogenomonas eutropha. Journal of Bacterio$\log y$ 95, 937-946.

Lascelles, J. (1968). The bacterial photosynthetic apparatus. Advances in Microbial Physiology 2, I-42.

LewIS, C. M. \& Fincham, J. R. S. (1970). Regulation of nitrate reductase in the basidiomycete Ustilago maydis. Journal of Bacteriology 103, 55-6r.

LiedtKe, M. P. \& OHMAnN, E. (I969). Eigenschaften und Regulation einer Phosphatase in Euglena gracilis, Synthese und Inaktivierung. European Journal of Biochemistry 10, 539-548.

Lin, E. C. C., Levin, A. P. \& MAgasanik, B. (1960). The effect of aerobic metabolism on the inducible glycerol dehydrogenase of Aerobacter aerogenes. Journal of Biological Chemistry 235, 1824-1829.

Lowry, O. H., Rosebrough, N. J., Farr, A. L. \& Randall, R. J. (I95I). Protein measurement with the Folin phenol reagent. Journal of Biological Chemistry 193, 265-275.

MANDELSTAM, J. (1964). Induced biosynthesis of lysine decarboxylase in Bacterium cadaveris. Journal of General Microbiology II, 426-437.

MeCKE, D. \& Holzer, H. (I966). Repression und Inaktivierung von Glutaminsynthetase in Escherichia coli durch $\mathrm{NH}_{4}{ }^{+}$. Biochimica et biophysica acta $\mathbf{1 2 2}, 34 \mathrm{I}-35 \mathrm{I}$.

MeCKE, D., WULfF, K. \& Holzer, H. (I966). Metabolit-induzierte Inaktivierung von Glutaminsynthetase aus Escherichia coli im zellfreien System. Biochimica et biophysica acta 128, 559-567.

NiJKAMP, H. J. J. (1969). Regulatory role of adenine nucleotides in the biosynthesis of guanosine 5'-monophosphate. Journal of Bacteriology 100, 585-593.

PoLLOCK, M. R. (1958). Enzymic 'de-adaptation': the stability of an acquired character on withdrawal of the external inducing stimulus. Proceedings of the Royal Society of London B r48, 340-352.

PrICE, C. A. (1962). Repression of acid phosphatase synthesis in Euglena gracilis. Science, New York 135, 46.

vaN RIJN, J. \& VAN WIJK, R. (1972). Differential sensitivities of the two malate dehydrogenases and the maltose permease to the effect of glucose in Saccharomyces carlsbergensis. Journal of Bacteriology n1o, 477-484. 
Robertson, J. J. \& Halvorson, H. O. (1957). The components of maltozymase in yeast and their behaviour during de-adaptation. Journal of Bacteriology 73, 186-198.

Schimke, R. T. \& Doyle, D. (1970). Control of enzyme levels in animal tissues. Annual Review of Biochemistry 39, 929-976.

Shapiro, B. M. \& Stadtman, E. R. (1970). The regulation of glutamine synthesis in microorganisms. Annual Review of Microbiology 24, 50I-524.

Sims, A. P. \& Ferguson, A. R. (1972). The role of enzyme inactivation in the regulation of glutamine synthesis in yeast: in vivo studies using ${ }^{15} \mathrm{~N}$. In 6. Wissenschaftliche Konferenz der Gesellschaft Deutscher Naturforscher und Ärtze. Second International Symposium on Metabolic Interconversion of Enzymes, Rottach-Egern, 197I, pp. 26I-276. Edited by O. Wieland, E. Helmreich and H. Holzer. Berlin, Heidelberg, New York: Springer Verlag.

Sims, A. P. \& Ferguson, A. R. (I974). The regulation of glutamine metabolism in Candida utilis: Studies with ${ }^{15} \mathrm{NH}_{3}$ to measure in vivo rates of glutamine synthesis. Journal of General Microbiology 8o, I 43-158.

Sims, A. P., Toone, J. \& Box, V. (I974). The regulation of glutamine synthesis in the food yeast Candida utilis: the purification and subunit structure of glutamine synthetase and aspects of enzyme deactivation. Journal of General Microbiology 80 (in the press).

Spiegelman, S. \& Reiner, J. M. ( 1947 ). The formation and stabilization of an adaptive enzyme in the absence of its substrate. Journal of General Physiology 3r, 175-193.

Stadtman, E. R., Ginsburg, A., Ciardi, J. E., Yeh, J., Hennig, S. B. \& Shapiro, B. M. (i970). Multiple molecular forms of glutamine synthetase produced by enzyme catalyzed adenylation and deadenylation reactions. Advances in Enzyme Regulation 8, 99-1 18.

Subramanian, K. N. \& Sorger, G. J. (1972). Regulation of nitrate reductase in Neurospora crassa: stability in vivo. Journal of Bacteriology 110, 538-546.

Thurston, C. F., John, P. C. L. \& Syretr, P. J. (I973). The effect of metabolic inhibitors on the loss of isocitrate lyase activity from Chlorella. Archiv für Mikrobiologie 88, I 35-145.

WeIMBERG, R. \& ORTON, W. L. (1965). Synthesis and breakdown of the polyphosphate fraction and acid phosphomonoesterase of Saccharomyces mellis and their locations in the cell. Journal of Bacteriology $\mathbf{8 9}$, $740-747$.

WIAME, J. M. (I 97I). The regulation of arginine metabolism in Saccharomyces cerevisiae: exclusion mechanisms. Current Topics in Cellular Regulation 4, I-38.

Williams, L. S. \& Neidhardt, F. C. (1969). Synthesis and inactivation of aminoacyl-transfer RNA synthetases during growth of Escherichia coli. Journal of Molecular Biology 43, 529-550.

Witt, I., KronaU, R. \& Holzer, H. (1966). Repression von Alkoholdehydrogenase, Malatdehydrogenase, Isocitratlyase and Malatsynthase in Hefe durch Glucose. Biochimica et biophysica acta 118, 522- 537. 